\title{
The effect of combination of indigenous phosphate solubilizing bacteria of Riau, Indonesia on the available phosphorus and phosphorus uptake of soybean
}

\author{
LUFITANUR ALFIAH ${ }^{1, \bullet}$, DELITA ZUL ${ }^{2}$, NELVIA NELVIA ${ }^{3}$ \\ ${ }^{1}$ Faculty of Agriculture, Universitas Pasir Pengaraian. Jl. Tuanku Tambusai, Rokan Hulu 28557, Riau, Indonesia. Tel.: +62- 762-7392272, \\ "email: lufitanuralfiah@gmail.com \\ ${ }^{2}$ Faculty of Mathematics and Natural Sciences, Universitas Riau. Bina Widya Campus, Jl. H.R. Soebrantas Road Km. 12,5, Pekanbaru 28293, Riau, \\ Indonesia \\ ${ }^{3}$ Faculty of Agriculture, Universitas Riau. Bina Widya Campus, J1. H.R. Soebrantas Road Km. 12,5, Pekanbaru 28293, Riau, Indonesia
}

Manuscript received: 20 April 2016. Revision accepted: 1 August 2018.

\begin{abstract}
Alfiah L, Zul D, Nelvia N. 2018. The effect of combination of indigenous phosphate solubilizing bacteria of Riau, Indonesia on the available phosphorus and phosphorus uptake of soybean. Nusantara Bioscience 10: 146-150. Despite the abundant amount of phosphorus $(\mathrm{P})$ in the soil, $\mathrm{P}$ uptake by the plants is very limited. In acidic soil, phosphorus $(\mathrm{P})$ is bound to aluminum $(\mathrm{Al})$ and iron $(\mathrm{Fe})$, whereas in the alkaline soil, phosphorus $(\mathrm{P})$ is bound to calcium $(\mathrm{Ca})$. The improvement of efficiency and availability of $\mathrm{P}$ to plants can be made by utilizing a group of solubilizing phosphate microorganisms. Potency test to investigate the $\mathrm{P}$ solubility by Phosphate Solubilizing Bacteria (PSB) has been conducted by isolating the bacteria from peat soil at Biosphere Reserves of Giam Siak Kecil Bukit Batu, Riau, Indonesia. The semi-quantitative test revealed that the PSB were able to dissolve $\mathrm{Ca} 3\left(\mathrm{PO}_{4}\right)_{2}, \mathrm{FePo}_{4}$ and phosphate rock. However, the adaptation ability and potency of PSB from indigenous Riau peat soil inoculated into soybean (Glycine max L. Merr) plants in the mineral soil have not yet been investigated. The present study was carried out from March to June 2015 on the alluvial soil in Babussalam Village, Rambah Sub-district, Rokan Hulu District, Riau. The aim of this study was to determine the effect of PSB inoculation on bacterial population and phosphatase activity. The study also aimed to determine the available $\mathrm{P}$ and $\mathrm{P}$ uptake and their impact on soybean growth and production. The study employed a factorial experiment laid out in a completely randomized design (CRD) consisted of two factors, i.e., soil treatment and PSB. The first factor comprised of two levels, i.e., $\mathrm{T}_{0}$ : non-sterilized soil, $\mathrm{T}_{1}$ : sterilized soil. The second factor consisted of 4 levels, i.e., $\mathrm{B}_{0}$ : without PSB inoculation, $\mathrm{B}_{1}$ : inoculation using 2 isolates of PSB (BB_UB6 and BB_K9), $\mathrm{B}_{2}$ : inoculation using 3 isolates of PSB (BB_UB6, BB_K9 and BB_K2), and B3: inoculation using 4 isolates of PSB (BB_UB6, BB_K9, BB_K2, and BB_HS13). The results showed that inoculation of starter 3 had the highest phosphatase activity rate of $12.43 \mu \mathrm{g} p \mathrm{NP} \mathrm{g}^{-1}$ hour $^{-1}$. The highest available $\mathrm{P}$ was produced by starter 2 , while the $\mathrm{P}$ uptake on non-sterilized soil was higher than that on the sterilized soil at $2.63 \mathrm{mg} \mathrm{plant}^{-1}$. PSB inoculation and soil sterilization did not significantly affect the population of phosphate solubilizing bacteria.
\end{abstract}

Keywords: Available P, P uptake, phosphate solubilizing bacteria, soybean

\section{INTRODUCTION}

Phosphate availability remains the main issue in the cultivation of soybean (Glycine $\max$ L. Merr) plants. Available $\mathrm{P}$ in the soil is abundant, but the concentration of $\mathrm{P}$ that can be absorbed by plants is very low. The concentration of available $\mathrm{P}$ in the soil is affected by the soil $\mathrm{pH}$ and soil type. In acidic soil, $\mathrm{P}$ is bound to aluminum ( $\mathrm{Al}$ ) and iron (Fe), whereas in the alkaline soil, $\mathrm{P}$ is bound to calcium $(\mathrm{Ca})$ and magnesium $(\mathrm{Mg})$. The presence of these bonds causes $\mathrm{P}$ to turn into chelate compounds absorbed with soil colloids; therefore, $\mathrm{P}$ is not available for plants. The provision of $\mathrm{P}$ fertilizer becomes less effective and efficient because a significant amount of $\mathrm{P}$ is bound through the absorption process. One possible effort to solve this problem is by using microorganisms from the phosphate solubilizing bacterial group (PSB) which can help release the $\mathrm{P}$ bond to make it available to the plants. The release of $\mathrm{P}$ bond is facilitated by the production of organic acids and phosphatase enzymes by
PSB. Additionally, PSB also produces growth promoting substance such as IAA and gibberellins acid that can increase plant growth.

Potency test to examine the P solubility by PSB isolated from peat soil at Biosphere Reserves of Giam Siak Kecil Bukit Batu, Riau, Indonesia has been conducted using a semi-quantitative approach resulted that the PSB were able to dissolve $\mathrm{Ca}_{3}\left(\mathrm{PO}_{4}\right)_{2}, \mathrm{FePO}_{4}$ and phosphate rock. However, a study focusing on the ability of adaptation and the potency of PSB originated from indigenous Riau peat soil and inoculated into soybean plants in the mineral soil have not been investigated yet. Thus, this study aimed at determining the effect of combined PSB isolates in improving available $\mathrm{P}$ and $\mathrm{P}$ uptake of soybean plants.

\section{MATERIALS AND METHODS}

This study was performed in two stages, namely laboratory work and field work during March to June 2015. 
Laboratory work was conducted in the Microbiology Laboratory of Biology Department, Faculty of Mathematics and Natural Sciences and Soil Laboratory of Faculty of Agriculture, University of Riau, Pekanbaru, Indonesia. Field research was carried out on the alluvial soil in Babussalam Village, Rambah Sub-district, Rokan Hulu, District, Riau Province, Indonesia.

The study employed a factorial experiment laid out in a completely randomized design (CRD) consisted of two factors, where the first factor, the soil treatment included two levels, i.e., $\mathrm{T}_{0}$ : non-sterilized soil, $\mathrm{T}_{1}$ : sterilized soil, while the second factor, PSB inoculation, consisted of 4 levels, i.e., $\mathrm{B}_{0}$ : without PSB inoculation, $\mathrm{B}_{1}$ : inoculation using 2 isolates of PSB (BB_UB6 and BB_K9), $\mathrm{B}_{2}$ : inoculation using 3 isolates of PSB (BB_UB6, BB_K9 and $\mathrm{BB}$ K2), and B3: inoculation using $\overline{4}$ isolates of PSB (BB_UB6, BB_K9, BB_K2, and BB_HS13).

\section{Preparation of PSB starter}

Starter 1 (a mixture of 2 PSB isolates): Starter 1 was made from two PSB isolates (BB_UB6 and BB_K9) by inoculating one ose of each bacterial isolate into $\overline{10} \mathrm{ml}$ of liquid Pikovskaya medium, which then incubated at room temperature for 24 hours with $150 \mathrm{rpm}$ agitation. After the incubation period, $10 \mathrm{ml}$ of each PSB inoculum was inoculated into an Erlenmeyer containing $40 \mathrm{ml}$ of liquid Pikovskaya. The culture was then incubated for 24 hours at room temperature with $150 \mathrm{rpm}$ agitation. After the incubation period, the two inoculum were mixed so as to produce inoculum 1 in $100 \mathrm{ml}$ volume consisting of a mixture of 2 isolates with a ratio of 1: 1 .

Starter 2 (a mixture of 3 PSB isolates): Starter 2 was made of three PSB isolates (BB_UB6, BB_K9, and BB_K2) by inoculating one ose of each bacterial isolate into $10 \mathrm{ml}$ of liquid Pikovskaya medium, then was incubated at room temperature for 24 hours with $150 \mathrm{rpm}$ agitation. After the incubation period, $5 \mathrm{ml}$ of each PSB inoculum was inoculated into Erlenmeyer containing $45 \mathrm{ml}$ of liquid Pikovskaya medium. The culture was then incubated for 24 hours at room temperature with $150 \mathrm{rpm}$ agitation. After the incubation period, the three inoculum were mixed so as to produce Starter 2 in $120 \mathrm{ml}$ volume consisting of a mixture of 3 PSB isolates with a ratio of 1: 1: 1 .

Starter 3 (a mixture of 4 isolate of PSB): Starter 3 was made following the same procedures of starter 1 and starter 2 , except that at the end of the inoculum preparation process, is the four PSB inoculum were mixed so as to produce Starter 3 in $100 \mathrm{ml}$ volume consisting of 4 PSB isolates with a ratio of $1: 1: 1: 1$.

\section{Preparation of growing media}

Topsoil was hoed for approximately $30 \mathrm{~cm}$ depth and then collected. The composite soil sample was then mashed using a shovel and sieved. The non-sterilized soil was put into the polybags as much as $5 \mathrm{~kg}$ polybag ${ }^{-1}$. The sterilized soil was prepared by employing the Tyndallization method, by gradually evaporating soil at $100^{\circ} \mathrm{C}$ for 1 hour and repeating the same process three times within 24 hours. The non-sterilized and sterilized soils were then let sit for about one day and then added with phosphate rocks at a dose of $0.75 \mathrm{~g} \mathrm{polybag}^{-1}$ and sterilized manure of $25 \mathrm{~g}$ polybag $^{-1}$. After one week, the growing media was ready to be used.

\section{Sterilization of seed surface, pre-germination, and inoculation}

The seeds were surfaced sterilized following the method of Hallmann et al. (1997). The soybean seeds were washed, and then immersed in $70 \%$ alcohol for one minute. The seeds were then immersed in $\mathrm{NaOCl} 2.5 \%$ for eight minutes and rinsed with sterile water for three times. The sterilized seeds were then pre-germinated by placing the seeds on the wet cotton until the seeds ruptured and germinated. Germinated seeds were then soaked with PSB starter according to treatment for 2 hours, after which the seeds were ready to be planted.

\section{Planting and maintenance}

The soybean seeds were sown by making planting holes on the prepared media in a three $\mathrm{cm}$ depth. Each hole was then filled with 2 seeds of soybean. After the seeds grow, thinning was done and 1 plant polybag ${ }^{-1}$ was retained up to harvest. Polybag arranged with a distance of $40 \mathrm{~cm} \mathrm{x} 40$ $\mathrm{cm}$. Fertilizer was added at a dose of $0.125 \mathrm{~g}^{-1}$ urea polybag ${ }^{-1}$ and $0.5 \mathrm{~g} \mathrm{KCl}_{\text {polybag }}{ }^{-1}$ was done at 20-30 days after planting.

\section{Data analysis}

Observations were made to determine the bacterial population, phosphatase activity rate, soil available $\mathrm{P}$, and $\mathrm{P}$ uptake. Obta8ned data were subjected to Analysis of Variance (ANOVA) using SAS 9.1 program. The treatment means were separated using a Duncan Multiple Range Test at $\alpha 5 \%$ significance level.

\section{RESULTS AND DISCUSSION}

PSB population tended to increase by the inoculations using starter 1, 2, and 3 as compared to no inoculation treatment both in sterilized and non-sterilized soils. PSB population in non-sterilized soil tended to be two times higher than that in the sterilized soil. PSB population in PSB inoculation using starter 1 tended to be higher, increased by nine times of the control treatment (Figure 1).

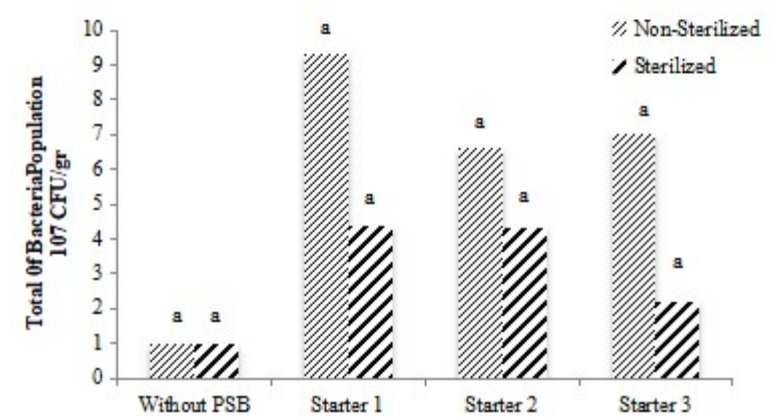

Starter $1=$ Mixture of 2 PSB isolates (BB_UB6 and BB_K9)

Starter $2=$ Mixture of 3 PSB isolates(BB_UB6, BB_K9 and BB_K2)

Starter $3=$ Mixture of 4 PSB isolates(BB_UB6, BB_K9, BB_K2 and BB_HS13)

Figure 1. The PSB population on non-sterilized and sterilized soil 30 days after inoculation 
Sterilized and non-sterilized soil media influenced the variation of PSB population in each treatment. On nonsterilized soil, inoculated PSB synergized positively with indigenous soil bacteria; therefore, the population of PSB on this type of soil was more abundant than that on the sterilized soil. A study by Cahyani (2009) revealed that soil sterilization significantly influenced the population of soil bacteria. Soil microbes affect one another resulting in very dynamic conditions in the rhizosphere (Lines-Kelly 2005). Bacteria within a community convey their presence to each other by producing, detecting, and responding to small signal molecules called autoinducers, and the process of intercommunication is called quorum sensing (Miller and Bassler 2001). Quorum sensing enables the starter bacteria and indigenous bacteria to interact positively, thereby causes the increase of bacterial activity. This study also indicated that PSB originating from peat soil was able to adapt to the new environment on mineral soils.

The PSB population found in this study is higher than that obtained by Fitriatin et al. (2009), where the population was only $1.70 \times 10^{6}$. On the other hand, the present study results are lower than the results obtained by Lestari et al. (2011) which ranged at 41-72 $\times 10^{8}$ at the end of the incubation period. Bacteria have the ability to grow and adapt according to their growing conditions and can utilize the nutrient sources contained in the substrate on the growth medium (Lestari et al. 2011).

\section{Phosphatase enzyme activity}

Soil sterilization has a significant effect on phosphatase enzyme activity in soil (Table 1). Phosphatase enzyme activity on non-sterilized soil increased 1.5 times higher than that on the sterilized soil. These results indicate that non-sterilized soil has higher phosphatase enzyme activity as a result of indigenous soil bacteria allowing the positive interaction among bacteria.

Mean phosphatase enzyme activity on sterilized soil was found lower than on the non-sterilized soil. The soil heating might have caused this during the sterilization process which affected the phosphatase enzyme in the soil. Nelson and Cox (2000) suggested that during enzymatic reactions, the rise in temperature increases the kinetic energy of reacting molecules; thereby it accelerates collisions among molecules. Collisions will facilitate the formation of substrate enzymes so that the product formed will be much more. At an optimum temperature, the collision between the enzyme and the substrate is very effective, so that the formation of the enzyme-substrate is easier and more products are formed. However, at a too high temperature, the collision will accelerate the damage to the formation of active enzyme groups (enzyme denaturation) in interacting with the substrate and the enzyme catalytic activity will decrease (Kilara and Harwalkar, 1996). Santosa (2009) also mentioned that soil sterilization has a significant effect on PSB activities.

Phosphatase enzyme activity was found higher in PSBinoculated growing media than that in non- inoculated growing media. This indicates that the PSB-inoculated growing media were capable of producing phosphatase enzymes. The formation of a clear zone (holozone) around the colony proved that the bacteria dissolved $\mathrm{P}$ through the production of phosphatase enzymes. The area of the clear zone qualitatively shows the level of bacteria's ability to dissolve $P$ from the insoluble phosphate (Rachmiati 1995).

The highest level of phosphatase activity in this experiment was produced by inoculation treatment using Starter 3 (12.43 $\mu \mathrm{gpNP} \mathrm{g}{ }^{-1}$ hour $\left.^{-1}\right)$. The result of the present study is higher than that reported by Suliasih and Rahmat (2007), where the activity of inoculated PSB phosphatase only ranged from 1.818 to $1.947 \mu \mathrm{g} \mathrm{pNP} \mathrm{g}^{-1}$ hour $^{-1}$. On the other hand, is the present results of phosphatase activity are lower than that reported by Tamad et al. (2013) at 30 $\mu \mathrm{gpNP} \mathrm{g}^{-1}$ hour $^{-1}$. Fitriatin et al. (2009) reported that the highest phosphatase activity was obtained in the inoculation of combined solubilizing phosphate bacteria with a phosphate solubilizing function of $201.50 \mu \mathrm{g} \mathrm{pNP} \mathrm{g}$ ${ }^{1}$ hour $^{-1}$.

The tendency of PSB population increase may affect the increase of phosphatase enzyme activity. The correlation between PSB population and phosphatase enzyme activity is presented in Figure 2.

The presented scatter plot shows that there was a positive correlation between the two variables, which means the higher population of bacteria; the higher is enzyme phosphatase activity. This condition proves that the increase in PSB population will also increase phosphatase enzyme activity. This finding also indicates the occurrence of quorum sensing where the behavior of bacteria depends on the population. Bacteria, in high population, convey their abilities, including phosphate solubilizing bacteria (PSB) (DeAngelis 2006). This notion is also in line with

Table 1. Phosphatase enzyme activity on non-sterilized and sterilized soils with PSB inoculation

\begin{tabular}{lccccc}
\hline & \multicolumn{5}{c}{ Phosphatase enzyme activity $(\boldsymbol{\mu g} \boldsymbol{p N P}$} \\
\cline { 2 - 5 } \multicolumn{1}{c}{ Soil type } & \multicolumn{4}{c}{$\mathbf{g}^{-1}$ hour $\left.^{-1}\right)$} \\
\cline { 2 - 5 } & Without & Starter & Starter & Starter & Mean \\
& PSB & $\mathbf{1}$ & $\mathbf{2}$ & $\mathbf{3}$ \\
\hline Non-sterilized & $8.72^{\mathrm{a}}$ & $13.60^{\mathrm{a}}$ & $9.87^{\mathrm{a}}$ & $16.43^{\mathrm{a}}$ & $12.15^{\mathrm{a}}$ \\
Sterilized & $5.80^{\mathrm{a}}$ & $9.91^{\mathrm{a}}$ & $8.32^{\mathrm{a}}$ & $8.43^{\mathrm{a}}$ & $8.11^{\mathrm{b}}$ \\
Mean & $7.26^{\mathrm{c}}$ & $11.75^{\mathrm{ab}}$ & $9.09^{\mathrm{bc}}$ & $12.43^{\mathrm{a}}$ & \\
\hline
\end{tabular}

Note: The numbers in the same rows and columns which is followed the same lowercase letter are not significantly different at $\alpha 5 \%$ DMRT.

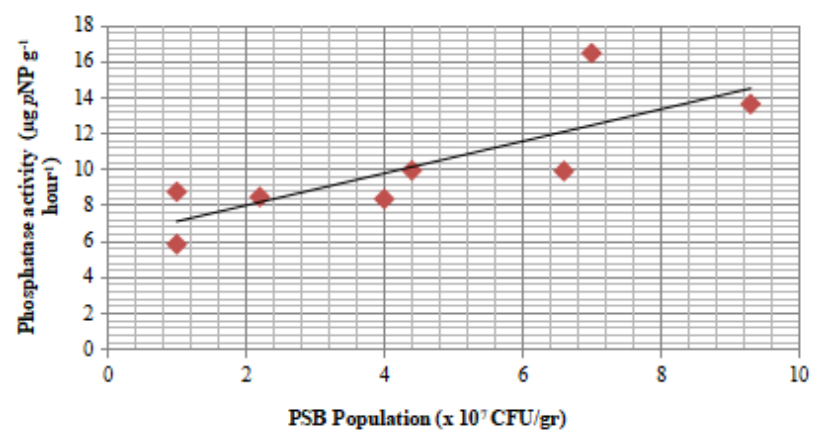

Figure 2. The correlation between PSB population and phosphatase activity. 
Table 2. Available $\mathrm{P}$ (ppm) and $\mathrm{P}$ uptake (mg.plant ${ }^{-1}$ ) on sterilized and non-sterilized soils 30 days after inoculation

\begin{tabular}{|c|c|c|c|c|c|}
\hline \multirow[b]{2}{*}{ Soil type } & \multicolumn{4}{|c|}{ Treatment } & \multirow[b]{2}{*}{ Mean } \\
\hline & $\begin{array}{c}\text { Without } \\
\text { PSB }\end{array}$ & $\begin{array}{c}\text { Starter } \\
1\end{array}$ & $\begin{array}{c}\text { Starter } \\
2\end{array}$ & $\begin{array}{c}\text { Starter } \\
3\end{array}$ & \\
\hline
\end{tabular}

\begin{tabular}{|c|c|c|c|c|c|}
\hline \multicolumn{6}{|c|}{ Available P (ppm) } \\
\hline Non-sterilized & $20.23^{\mathrm{a}}$ & $24.88^{\mathrm{a}}$ & $36.94^{\mathrm{a}}$ & $36.30^{\mathrm{a}}$ & $29.59^{\mathrm{a}}$ \\
\hline Sterilized & $8.41^{\mathrm{a}}$ & $26.34^{\mathrm{a}}$ & $29.25^{\mathrm{a}}$ & $22.49^{\mathrm{a}}$ & $21.62^{\mathrm{a}}$ \\
\hline Mean & $14.32^{\mathrm{b}}$ & $25.61^{\mathrm{ab}}$ & $33.10^{\mathrm{a}}$ & $29.40^{\mathrm{a}}$ & \\
\hline \multicolumn{6}{|c|}{$P$ uptake (mg plant ${ }^{-1}$ ) } \\
\hline Non-sterilized & $1.90^{\mathrm{a}}$ & $1.52^{\mathrm{a}}$ & $0.69^{\mathrm{a}}$ & $6.42^{\mathrm{a}}$ & $2.63^{\mathrm{a}}$ \\
\hline Sterilized & $0.51^{\mathrm{a}}$ & $0.67^{\mathrm{a}}$ & $0.51^{\mathrm{a}}$ & $0.36^{\mathrm{a}}$ & $0.51^{\mathrm{b}}$ \\
\hline Mean & $1.21^{\mathrm{a}}$ & $1.10^{\mathrm{a}}$ & $0.60^{\mathrm{a}}$ & $3.39^{\mathrm{a}}$ & \\
\hline
\end{tabular}

Note: The numbers in the same rows and columns which is followed the same lowercase letter are not significantly different at $\alpha 5 \%$ DMR test.

the notion of Tamad et al. (2013) which stated that the PSB population was positively correlated with phosphatase activity. Phosphatase enzyme activity in the soil is closely related to microbial activity because microbial biomass is the primary source of enzymes in the soil. Suliasih et al. (2010) reported that phosphatase enzyme activity on tomato-growing soil increased in line with the increasing population of solubilizing phosphate bacteria.

\section{Available P}

PSB inoculation increased the available $\mathrm{P}$ of the soil as much as twice higher than that without inoculation (Table 2). Starter 2 treatment produced the highest available $P$ by $33.10 \mathrm{ppm}$. However, the major effect of soil sterilization and the interaction of the two treatments did not significantly increase the soil available P. Non-sterilized soils tended to contain higher available $\mathrm{P}$ compared to sterilized soil.

A significant increase of available $\mathrm{P}$ indicates that PSB from Bukit Batu peat soil are able to adapt well to mineral soil in Rokan Hulu District. The increase in soil available P in this study is much higher than the increase in available $\mathrm{P}$ from the adding of PSB in Sei Garo (Lestari et al. 2011) at $16.2 \mathrm{ppm}$. Bacterial isolates have different adaptability to their newly grown environment. Widyati (2007) stated that the ability of bacteria in dissolving $\mathrm{P}$ depends on the process of their own isolate metabolism. PSB activity in dissolving $\mathrm{P}$ is highly dependent on soil temperature, soil moisture, $\mathrm{pH}$, food supply and environmental conditions during their growth (Widawati and Suliasih 2006).

Table 2 shows that the main effect of soil sterilization increased $\mathrm{P}$ uptake in soybean plants. It may be concluded that soybean plants were able to absorb $\mathrm{P}$ better in nonsterilized soil than in sterilized soil. Available P in nonsterilized soil was five times higher than that in sterilized soil. However, inoculated PSB isolate mixture and treatment interaction did not significantly increase the $\mathrm{P}$ uptake by soybean.

This condition indicates the influence of indigenous soil microbes in providing $\mathrm{P}$ nutrient to the non-sterilized soil was the result of higher bacterial diversity. However, the role of indigenous microbes in providing soil $\mathrm{P}$ is insufficient to increase soil $\mathrm{P}$ uptake. The high available $\mathrm{P}$ found in this study was not in line with the high absorption of $\mathrm{P}$ by the soybean plants, which is indicated by the low mean $\mathrm{P}$ absorption by soybean plants due to sterilization that ranged from 0.51 to $2.63 \mathrm{mg}$ plant $^{-1}$. Saidi (2002) stated that soil P is closely related to P uptake; thus the higher is the soil $\mathrm{P}$, the higher is the $\mathrm{P}$ uptake in plants. Jones et al. (1991) suggested that P uptake is categorized as low in the range of 1.6 to $2.6 \mathrm{mg} \mathrm{plant}^{-1}$.

The low absorption of $\mathrm{P}$ may be caused by the nutrient limiting factor in the soil. The low content of sodium and magnesium in the soil before the study caused the inhibition of $\mathrm{P}$ absorption by plants. Besides, $\mathrm{Mg}$ is a crucial nutrient that plays a role in the photosynthesis process. Syafii (2008) stated that $\mathrm{Mg}$ has a vital role in chlorophyll synthesis. The low content of $\mathrm{Mg}$ element may decrease the level of chlorophyll and, hence the photosynthesis rates; thus the photosynthesis products are not optimally produced. The $\mathrm{P}$ absorption by soybean plants in this study was lower than that reported by Lestari et al. (2011) (58.3 mg plant $\left.{ }^{-1}\right)$. We concluded from the present study findings that PBS inoculation and soil sterilization can increase soil phosphatase activity and available $\mathrm{P}$. The results also indicate that the two variables have no significant effect on bacterial population and $\mathrm{P}$ uptake of soybeans.

\section{ACKNOWLEDGEMENTS}

The authors appreciate and thank Nia Sufika Indriani for the significant assistance provided to the author during this research.

\section{REFERENCES}

Cahyani VR. 2009. Influence of soil sterilization methods on nutrient status, microbiota population, potential of mycorrhizal infection and plant growth. Soil Science 6 (1): 43-52

De Angelis KM. 2006. Microbial Community Ecology and Bacterial Quorum Sensing as Control Points in Rhizosphere Nitrogen Cycling. [Dissertation]. The University of California. Berkeley, CA.

Fitriatin BN, Joy B, Subroto T. 2009. The Influence of Organic Phosphorous Substrate on Phosphatase Activity of Soil Microbes, Proceeding International Seminar of Chemistry, Universitas Padjadjaran, Jatinangor, Indonesia, 30-31 Oktober 2008.

Hallmann J, Quadt-Hallmann A, Mahaffee WF, Kloepper JW. 1997. Bacterial endophytes in agricultural crops. J Microbiol 43(10): 895914.

Jones JB, Wolf B, Mills HA. 1991. Plant Analysis Handbook.MicroMacro Publishing, Inc. Georgia. USA.

Kilara A, Harwalkar VR. 1996. Denaturation. In Food Proteins: Properties and Characterization. VCH Publishers. New York.

Lestari, Wahyu TM, Linda, Martina A. 2011. The ability of seigaro's phosphate solubilizing bacteria in provision of dissolved phosphate and its absorption on soybean plants. Biospecies 4 (2): 1-5.

Lines-Kelly R. 2005. Defend The Rhizosphere and Root Against Pathogenic Microorganism. Department of Primary Industries, State of New South Wales, Sydney.

Miller MB, Bassler BL. 2001. Quorum sensing in bacteria. Ann Rev Microbiol 55: 99-165.

Nelson DL, Cox MM. 2000. Lehninger Principles of Biochemistry. 3rd ed. Worth Publisher, New York. 
Rachmiati Y. 1995. Phosphate solubilizing bacteria from plant rhizosphere and its ability in dissolving phosphate. Proceedings of the Nationa Congress VI HITI Volume 1. Land Use as a Spatial Planning Tool to Improve Human's Welfare, Soil Science Association of Indonesia. Jakarta, 12-15 December 1995.

Saidi D. 2002. Isolation and characterization of cellulolytic bacteria and phosphate solubilizer from andisol as biological fertilizer agent Habitat 8 (4): 201 - 211.

Santosa E. 2009. The activity of Some Bacteria Solubilizing Phosphate Isolatesat Various Levels C-Organic in Ultisols Soil. Soil Research Institute. Bogor

Suliasih R. 2007. Phosphatase activity and calcium phosphate dissolution by some Phosphate Solubilizing Bacteria. Biodiversitas 8: 23-26.
Syafi S. 2008. Morphological and Physiological Response of Different Genotypes Seeds of Jatropha (Jatropha curcas L.) to Drought Stress. [Thesis]. Bogor Agricultural University, Bogor. [Indonesia]

Tamad, Ma'as A, Radjagukguk B, Hanudin E, Widada J. 2013. Availability of phosphorus in andisol soil for maize (Zea mays L.) by phosphate solubilizing bacterial inoculum. J Agron. 41 (2): 112-117

Widawati S, Suliasih. 2006. Augmentation of potential Phosphate Solubilizing Bacteria (PSB) for growth of spur caysim (Brasicaca ventis Oed.) in marginal land. Biodiversitas 7 (1): 10-14.

Widyati E. 2007. Utilization of sulfate-reducing bacteria for bioremediation of coal mine former land. Biodiversitas 8 (4): 283286. 